\title{
Efektivitas Tumpangsari Kunyit Terhadap Penekanan Nematoda Sista Kuning pada Kentang
}

\author{
Dini Munawaroh1), Subagiya²), Susilo Hambeg Poromarto²)
}

\begin{abstract}
Golden cyst nematode is one of the important pests that causes potatoes loss yield. Globodera rostochiensis is the pest that difficult to control because it can withstand in adverse environmental conditions. In Indonesia, golden cyst nematode was first discovered in 2003 in East Java. One of the methods that used in this research is intercropping system. The main objectives in this study was to examine how the effect of turmeric plants on intercropping system to cysts population and amount of eggs on golden cyst nematode and the use of turmeric plants is expected to reduce the application of nematicides. This research was conducted on November 2017-February 2018, in Dieng Banjarnegara. The results show the effect of turmeric on intercropping system had not been able to control the cysts population through the eggs, beside that the eggs are not decrease due to genetic factors of each nematode and environment that effect on eggs formation. But the balancing of use turmeric plants on intercropping system could reduce the cysts population. It can be seen on K1P1 (1 Potato : 1 Turmeric) treatment that showed of decreases of cysts population compared to control treatment. The difference on cysts population is caused by turmeric root exudates.
\end{abstract}

Keyword: Globodera rostochiensis, Curcuma longa, cysts

\section{PENDAHULUAN}

Produksi kentang di Indonesia sangat fluktuatif. Pada tahun 2017 produksi kentang belum mencapai target sesuai dengan perencanaan yang telah dibuat. Target produksi kentang tahun 2017 sebesar 1.437.332 ton dan Direktorat Jenderal Hortikultura berhasil merealisasikan sebesar 1.235.180 ton. Rata-rata pertumbuhan produksi kentang sebesar 6,68\%. Produksi kentang yang fluktuatif ini disebabkan karena adanya perubahan luas lahan dan adanya serangan OPT tular tanah yang mulai endemik seperti nematoda sista kuning (NSK) (Dirjen Horti 2017). Berbagai kendala produksi yang dihadapi meliputi hama dan patogen yang menyebabkan kehilangan hasil panen. Salah satu faktor yang penting dalam pengurangan hasil adalah nematoda. Berdasarkan USDA (2012) nematoda sista kuning termasuk kategori hama yang sulit untuk dikendalikan karena dapat bertahan disaat kondisi lingkungan yang tidak menguntungkan.

Menurut Dirjen Hortikultura (2003), kentang dapat mengalami penurunan produksi yang disebabkan oleh NSK sebesar $70 \%$ dari produksi normal 25 ton/ha menjadi 10 ton/ha. Menurut Achrom et al (2011) penurunan hasil secara nasional adalah 133.062 ton senilai Rp. 532.284.000.000. penurunan hasil dapat meningkat jika populasi NSK disuatu tempat meningkat dan dapat menurunkan hasil sebesar $80 \%$. Pengendalian nematoda yang sering dilakukan oleh petani adalah dengan menggunakan nematisida. Salah satu kontrol secara alami dapat dilakukan dengan rotasi tanaman, yaitu dapat berupa tumpangsari.

1) Mahasiswa S1 Program Studi Agroteknologi, Fakultas Pertanian, Universitas Sebelas Maret

2) Staf Dosen Program Studi Agroteknologi, Fakultas Pertanian, Universitas Sebelas Maret

Author Contact: dinimunawaroh10@gmail.com
Penggunaan sistem tumpangsari untuk tanaman semusim sudah dilakukan sejak lama, karena memiliki fungsi tersendiri salah satunya sebagai tanaman penjebak maupun tanaman pagar untuk pengelolaan hama yang berada di lahan, selain itu tumpangsari juga dapat meningkatkan produksi dari tanaman sampingan yang digunakan. Penggunaan sistem tumpangsari membutuhkan pertimbangan untuk pertumbuhan tanaman utama, salah satu tanaman sampingan yang digunakan untuk tumpangsari adalah kunyit yang memiliki banyak manfaat pada rimpangnya. Pemilihan kunyit sebagai tanaman sampingan dikarenakan kunyit memiliki kandungan minyak atsiri yang diduga dapat mengontrol dalam pengelolaan populasi nematoda. Tujuan dari penelitian ini untuk mengetahui pengaruh penggunaan tumpangsari kunyit sebagai salah satu cara pengelolaan sista dan telur nematoda yang menyerang kentang.

\section{METODE PENELITIAN}

Penelitian dilaksanakan September 2017 sampai Juni 2018 di Desa Dieng Kulon, Kecamatan Batur, Kabupaten Banjarnegara dan Laboratorium Hama dan Penyakit Tumbuhan Fakultas Pertanian, Universitas Sebelas Maret, Surakarta. Alat yang digunakan dalam penelitian ini antara lain mikroskop, hand counter, petridish, pinset, silet, tisu, centrifuge, saringan bertingkat, lup dan gelas ukur. Bahan yang digunakan dalam penelitian ini adalah umbi kentang, rimpang kunyit, gula pasir, aquades, sampel tanah.

Penelitian ini dilaksanakan dengan melakukan identifikasi nematoda sista kuning di lahan, serta melakukan ektraksi nematoda dengan metode FlotasiSentrifugasi. Sampel tanah diambil sebanyak $100 \mathrm{~g}$ dan dilarutkan kedalam $300 \mathrm{ml}$ air. Hal ini sesuai dengan 
Coyne et al (2003) yang menjelaskan bahwa pengambilan sista nematoda berasal dari hasil ekstraksi $100 \mathrm{ml}$ tanah dan $10 \mathrm{~g}$ akar segar yang berasal dari sampel. Penelitian ini menggunakan rancangan acak lengkap (RAL) dengan 1 faktor yaitu perlakuan tumpangsari kunyit, dan terdiri dari 3 taraf. Taraf tersebut terdiri dari jumlah kentang yang digunakan, antara lain dengan 1 kentang, 2 kentang, dan 3 kentang. Sehingga diperoleh kombinasi perlakuan sebagai berikut:

Kontrol = tanpa kunyit

K1P1 = 1 kentang : 1 kunyit

$\mathrm{K} 1 \mathrm{P} 2=2$ kentang : 1 kunyit

K1P3 = 3 kentang : 1 kunyit

Setiap perlakuan diulang sebanyak 9 kali, diperoleh 27 kombinasi perlakuan ditambah dengan 3 perlakuan kontrol sebagai pembanding. Variabel yang diamati adalah populasi sista nematoda yang berada di tanah serta pertumbuhan tanaman dan melakukan pengamatan pada nematoda.

\section{HASIL DAN PEMBAHASAN}

Populasi sista dan jumlah telur nematoda terlihat mengalami penurunan (Tabel 1). Perbedaan jumlah sista diduga disebabkan karena adanya pengaruh penggunaan kunyit yang mengandung minyak atsiri sehingga dapat menurunkan jumlah sista nematoda yang ada diperlakuan K1P1 dibandingkan dengan perlakuan kontrol. Perlakuan K1P2 dan K1P3 yang menggunakan kentang lebih banyak daripada perlakuan K1P1 memperlihatkan hasil sista yang lebih banyak, hal ini diduga karena jumlah kunyit yang tidak sebanding dengan jumlah kentang yang digunakan dalam sistem tumpangsari. Apabila kunyit yang digunakan sebanding dengan banyaknya kentang, diduga dapat mengurangi jumlah sista.

Sista pada tiap perlakuan memiliki jumlah yang fluktuatif, dimana untuk perlakuan K1P1 memiliki sista paling sedikit dengan perlakuan yang lainnya (Tabel 1), hal ini disebabkan karena perbandingan jumlah kunyit yang digunakan seimbang dengan jumlah kentang yang ditanam. Kunyit mengandung senyawa etanol yang dapat mempengaruhi jumlah sista dalam perlakuan tumpangsari yang digunakan.

Tabel 1 Pengaruh penerapan sistem tumpangsari kunyit terhadap jumlah sista dan telur nematoda di dalam tanah

\begin{tabular}{ccc}
\hline $\begin{array}{c}\text { Perlakuan } \\
\text { (kentang : kunyit) }\end{array}$ & $\begin{array}{c}\text { Sista } \\
\text { (per 100 ml tanah) }\end{array}$ & $\begin{array}{c}\text { Telur } \\
\text { (per sista) }\end{array}$ \\
\hline Tanpa kunyit & 317,67 & $181,80^{\mathrm{a}}$ \\
$1: 1$ & 239,00 & $194,69^{\mathrm{ab}}$ \\
$2: 1$ & 317,11 & $249,09^{\mathrm{b}}$ \\
$3: 1$ & 297,78 & $224,98^{\mathrm{ab}}$ \\
\hline
\end{tabular}

Keterangan: Angka pada kolom sama yang diikuti huruf sama tidak berbeda nyata pada uji jarak berganda Duncan $(P<0,05)$

Hal ini sesuai dengan Indrawan et al (2017) bahwa senyawa etanol dapat menyebabkan terjadinya lisis pada sista maupun larva nematoda sista kuning, selain itu juga berdasarkan penelitian dari Kusbiantoro dan Purwaningrum (2018) menunjukkan bahwa kandungan metabolit sekunder rimpang kunyit dalam keadaan segar lebih tinggi dibandingkan rimpang kunyit yang kering, sehingga kadar minyak atsiri dan oleoresin etanol pada rimpang segar lebih tinggi. Menurut Koswara (2009) cit. Sholehah et al (2016), kunyit memiliki senyawa utama yang berupa minyak atsiri serta kurkumin selain demetoksikurkumin, dan bisdemetoksikurkumin. Minyak atsiri yang terkandung didalam rimpang kunyit terdiri dari tumeron, tumerol, kariofilen, linalool dan sineol. Menurut Usman et al (2009) kandungan monoterpene dalam minyak atsiri yang paling melimpah adalah 1,8-cineol $(6,9 \%)$. Selain itu Borneol (3,3 \%), terpine-4-ol $(2,1 \%)$ dan terpineol $(2,0 \%)$ yang ada dalam jumlah yang lumayan banyak.

Berdasarkan Damalas (2011), kunyit telah digunakan sejak lama sebagai bahan efektif untuk mengendalikan hama karena bahan bioaktif yang terkandung dalam kunyit. Kandungan aktif dalam kunyit dapat digunakan sebagai penolak serangga dan bahan insektisida. Bagian dari kunyit yang digunakan sebagai pengendali hama adalah bubuk kunyit, hasil ekstrak, minyak esensial yang terkandung dan beberapa bahan bioaktif yang terkandung didalamnya.

Menurut Dandurand et al (2016) kendala yang menjadi penghambat dalam pengendalian nematoda sista pada kentang adalah karena adanya sista nematoda yang mengandung ratusan telur didalam tubuhnya. Sista melindungi telur nematoda dimana telur dalam keadaan inaktif dan dilindungi dari senyawa kimia maupun biologi yang disebabkan oleh kondisi tanah yang mengalami stress. Telur yang berada didalam sista dapat bertahan selama beberapa dekade didalam tanah. Telur akan menetes dengan adanya eksudat yang dihasilkan oleh akar kentang dan menghasilkan nematoda muda (juvenile) yang mulai menyerang tanaman.

Berdasarkan hasil penelitian yang telah dilakukan oleh Mimee et al (2015) menunjukkan bahwa pengetahuan yang baik tentang siklus hidup Globodera rostochiensis perlu dikaji selama melakukan budidaya kentang. Penggunaan tanaman perangkap dapat memicu penetasan telur NSK dengan eksudat akar yang dihasilkannya dan menghambat nematoda bereproduksi. Penggunaan kultivar yang tahan tidak cukup untuk mengendalikan populasi nematoda di dalam tanah. Penggunaan tanaman perangkap akan menghambat kenaikan populasi nematoda. Hal ini terlihat dari jumlah sista nematoda awal yang masih berwarna putih berkurang dari 42 sista menjadi 28 sista, sehingga tanaman perangkap dapat mengurangi jumlah sista nematoda dalam fase awal.

Populasi sista yang menurun dapat juga disebabkan karena faktor dalam penghitungan kerapatan sista persatuan sampel tanah yang diekstraksi (Bacic et al 2013). Populasi sista (Tabel 1) menurun, hal ini bisa saja disebabkan karena faktor kesalahan dalam penghitungan sista. Sista yang berwarna coklat keemasan seringkali menyerupai partikel tanah, sehingga dalam penghitungannya perlu ketelitian yang tinggi. Faktor lain yang dapat menurunkan sista adalah faktor lingkungan. 
Telur nematoda yang diamati dari hasil perlakuan tumpangsari kunyit menunjukan bahwa jumlah telur meningkat (Tabel 1). Jumlah telur untuk perlakuan kontrol paling sedikit dibandingkan dengan perlakuan tumpangsari yang diberikan. Pengaplikasian tumpangsari kunyit tidak memberikan pengaruh terhadap pembentukan telur nematoda yang berada didalam tubuh sista. Hal ini dapat disebabkan karena dinding tubuh sista memilki kutikula yang tebal yang dilapisi oleh protein sehingga eksudat akar kunyit tidak bisa memberikan pengaruh terhadap pembentukan telur didalam sista. Penetasan telur nematoda dipicu oleh adanya eksudat akar dari tanaman inang (Clarke dan Perry 1977 cit. Cronin et al 1997). Sista dapat mengandung telur lebih dari 300 telur didalam tubuhnya, sehingga proses penetasan telur yang terjadi akan sangat bergantung dengan kondisi tanaman inang dan juga eksudat akar lain yang ada berada di lahan yang sama.

Telur nematoda dapat bertahan selama lebih dari 20 tahun. Berdasarkan penelitian yang dilakukan Dandurand et al (2016) penggunaan tanaman sampingan yang bukan dari inangnya dapat menstimulasi penetasan telur nematoda tanpa mendukung proses reproduksi nematoda. Tanaman perangkap yang digunakan dapat membatasi sumber makanan nematoda didalam tanah, sehingga nematoda bisa saja mati jika tidak menemukan sumber makanan yang berasal dari inangnya. Menurut Chitwood (2002) penggunaan senyawa kimia yang dimiliki oleh akar tanaman lain dapat digunakan untuk mengetahui interaksi yang ditimbulkan antara nematoda dengan akar tanaman tersebut. Penggunaan senyawa kimia dari akar tanaman lain ini bisa saja bersifat repelen, antraktan, atau penstimulan maupun penghambat, dan nematoksikan yang mempengaruhi dalam pembentukan sista nematoda maupun ada tidaknya nematoda di suatu lahan.

Ketika kentang ditanam di tanah yang sudah terinfestasi oleh NSK, senyawa kimia yang diproduksi oleh akar tanaman kentang dapat menstimulasi penetasan telur NSK, namun beberapa sista dapat mengalami dormansi yang disebabkan karena lingkungan yang tidak mendukung maupun faktor genetik yang mempengaruhi penetasan telur NSK. Walaupun tanaman inang menghasilkan senyawa kimia untuk penetasan telur, namun hanya sedikit telur yang merespon stimulus dari akar kemudian menetas. Di saat situasi seperti itu, walaupun terdapat inang hanya sedikit proporsi telur NSK yang menetas dari keseluruhan jumlah total telur yang merespon stimulus dari difusi akar, kemudian menetas. Beberapa saat kemudian, dormansi akan menghilang karena perubahan iklim yang berubah menjadi cocok atau ketika adanya faktor edogen yang membuat nematoda dapat menerima stimulus yang dihasilkan dari tanaman inang (Gonzales dan Phillips 1996).

Jumlah sista saat sebelum masa tanam dengan perlakuan tumpangsari kunyit dan pemberian nematisida yang telah dilakukan oleh petani memiliki perbedaan dimana untuk perlakuan nematisida jumlah sista dan telur nematoda menurun (Gambar 1).

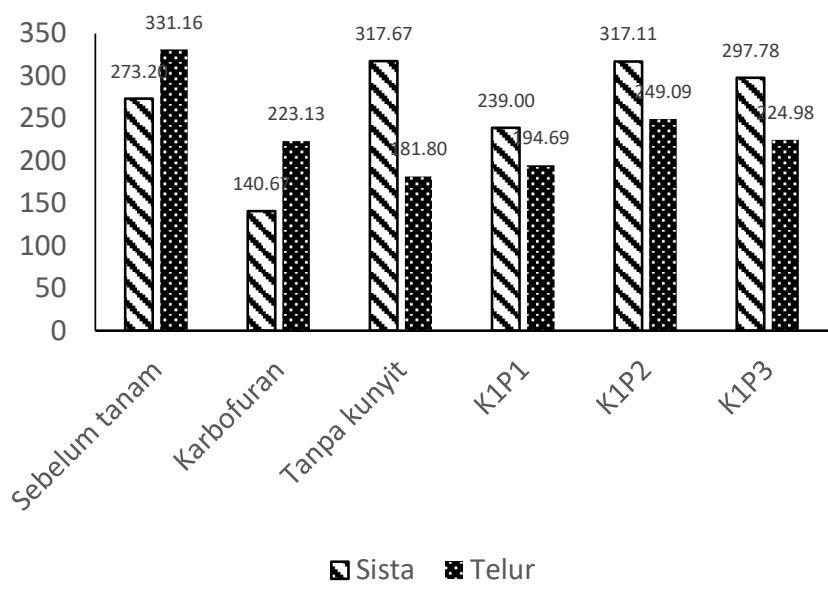

Gambar 1. Perbandingan jumlah sista dan telur pada perlakuan tumpangsari kunyit dengan saat sebelum masa tanam dan perlakuan nematisida yang dilakukan petani

Perbandingan populasi sista dan telur nematoda dilakukan pada saat sebelum masa tanam, dimana lahan tersebut ditanami dengan kentang terus menerus tanpa adanya rotasi tanaman. Kemudian penggunaan kunyit sebagai tumpangsari dilakukan untuk mengetahui bagaimana pengaruh kunyit terhadap nematoda, sista maupun telur nematoda. Penggunaan kunyit ini terlihat tidak memberikan pengaruh yang signifikan karena persebaran akar kunyit yang kurang maksimal sehingga jangkauan terhadap nematoda maupun sista kurang maksimal. Penggunaan tumpangsari kunyit ini menggunakan kentang dengan jumlah yang berbeda pada tiap perlakuan. Perlakuan K1P1 menunjukkan bahwa jumlah sista yang lebih sedikit dibandingkan dengan perlakuan lainnya, kecuali dengan penggunaan nematisida (Gambar 1).

Penggunaan nematisida yang dilakukan oleh petani memang dapat menurunkan jumlah sista dibandingkan dengan penggunaan tumpangsari kunyit yang telah dilakukan. Penggunaan karbofuran mampu menurunkan populasi sista (Gambar 1). Berdasarkan penelitian yang telah dilakukan oleh Seenivasan (2017) penggunaan karbofuran dapat mengurangi populasi NSK sebanyak $91,0 \%$ di tanah dan pada umbi sebanyak $84,6 \%$. Namun hal ini dapat memberikan dampak yang kurang baik bagi lingkungan, karena pada pengaplikasiannya nematisida tidak mengenai langsung nematoda yang berada di dalam tanah, namun mengenai permukaan tanah. Hal ini sesuai dengan Chitwood (2002) yang menyatakan bahwa penggunaan nematisida sebagai pengendalian nematoda masih belum efektif, karena penggunaannya yang tidak secara lingkungan sehingga penggunaan nematisida ini masih banyak memiliki kekurangan

Pertumbuhan tanaman kentang terlihat tidak maksimal, hal ini terlihat pada tinggi rata-rata tanaman kentang yang ditumpangsarikan dengan kunyit terlihat pendek daripada tinggi tanaman kentang pada umumnya (Tabel 2). Tinggi tanaman kunyit yang terlihat lebih pendek ini bisa dipengaruhi oleh berbagai faktor, salah satunya kerapatan tanaman perpolybag sehingga menyebabkan kompetisi yang terjadi dan membuat 
tanaman kentang berebut unsur hara dengan tanaman kunyit yang ditumpangsarikan, walaupun jarak pertanaman setiap polybag diatur $15 \mathrm{~cm} \times 15 \mathrm{~cm}$. Faktor lain yang mempengaruhi tanaman kentang menjadi kerdil adalah karena adanya nematoda yang berada disekitar perakaran tanaman, sehingga mempengaruhi pertumbuhan tanaman.

Table 2 Pengaruh tumpangsari terhadap tinggi kentang

\begin{tabular}{lcc}
\hline No & Perlakuan & Tinggi tanaman (MST) \\
\hline 1 & Kontrol & $7,75^{\mathrm{a}}$ \\
2 & K1P1 & $14,08^{\mathrm{b}}$ \\
3 & K1P2 & $7,04^{\mathrm{a}}$ \\
4 & K1P3 & $8,63^{\mathrm{a}}$ \\
\hline
\end{tabular}

Keterangan: Angka pada kolom sama yang diikuti huruf sama tidak berbeda nyata pada uji jarak berganda Duncan $(\mathrm{P}<0,05)$.

Tumpangsari yang diterapkan adalah menggunakan kunyit sebagai tanaman sampingan yang ditanam bersamaan dengan kentang dalam satu polybag. Tanaman yang digunakan setiap polybag memiliki jumlah yang berbeda, terdiri dari kentang dan kunyit sesuai dengan perlakuan sehingga menimbulkan kompetisi karena kerapatan tanaman yang berbeda setiap polybag. Kompetisi yang terjadi menyebabkan salah satu tanaman mengalami pertumbuhan yang terhambat. Tanaman kentang memiliki tinggi yang sangat rendah karena tidak mendapatkan cukup ruang dalam fase vegetatif. Pertumbuhan gulma juga menjadi salah satu faktor penghambat dalam pertumbuhan tanaman kentang, sehingga banyak tanaman kentang yang mengalami kompetisi yang semakin tinggi.

Tinggi tanaman pada setiap minggunya hanya mengalami sedikit kenaikan. Rata-rata tinggi tanaman tertinggi pada perlakuan K1P1 dengan tinggi $14,08 \mathrm{~cm}$ (Tabel 2). Polybag yang digunakan dalam penelitian ini berukuran $60 \mathrm{~cm}$. Polybag ditanam kedalam tanah agar tetap menjaga suhu tanah tetap sama. Penerapan tumpangsari yang telah diaplikasikan menunjukkan bahwa tanaman kentang tidak bisa tumbuh dengan baik karena kerapatan tanaman yang terlalu tinggi dengan jarak tanam $15 \mathrm{~cm} \times 15 \mathrm{~cm}$. Hal ini berbeda dengan pendapat Amirullah dan Hadiyanti (2014) yang menyatakan bahwa laju pertumbuhan tinggi tanaman kentang akan semakin tinggi jika jarak tanam yang diterapkan semakin rapat. Namun berdasarkan penelitian tumpangsari kunyit dengan kentang yang sudah dilakukan, tinggi kentang tidak bisa berkembang secara maksimal, hal ini bisa saja disebabkan karena pemilihan tanaman yang kurang cocok untuk tanaman sampingan untuk budidaya kentang.

Berbagai sistem pertanian memiliki aktivitas kompleks yang berasal dari aktivitas tanaman yang dibudidayakan. Sistem tumpangsari yang menjadi salah satu contoh cara budidaya dapat meningkatkan hasil panen. Hal ini bergantung pada jenis tanaman yang dibudidayakan. Hasil pertanian yang didapat selama penggunaan sistem yang modern dapat ditopang oleh sumber daya eksternal yang bernilai lebih tinggi. Penggunaan sistem ini bertujuan sebagai pengurangan degradasi pada ekosistem lahan. Untuk itu dikembangkan sistem pertanian yang memiliki aspek ekologi dan socsal ekonomi yang menunjang agroekosistem yang hemat energi dan mengurangi penggunaan sumber daya yang terlalu banyak (Altieri et al 1983).

Penggunaan sistem tumpangsari menyediakan berbagai cara untuk mengontrol serangga hama yang menyerang pertanaman dengan tanpa menggunakan bahan kimia, karena penggunaan tumpangsari dapat dijadikan sebagai salah satu cara kontrol alami pada hama. Selain itu penggunaan tumpangsari dapat meningkatkan pendapatan petani dan mengurangi biaya kontrol terhadap hama dan penyakit. Berdasarkan hasil penelitian yang telah dilakukan oleh Sharaby dan peneliti lainnya menyatakan, penggunaan sistem tumpangsari dapat menjadi salah satu cara alternatif yang digunakan untuk mengurangi populasi hama di lahan (Sharaby et al 2015).

\section{KESIMPULAN}

1. Populasi sista pada perlakuan 1 kentang dengan 1 kunyit (239,00 sista) lebih sedikit dibandingkan dengan perlakuan kontrol (317,67 sista). Perbedaan populasi sista ini dapat disebabkan karena adanya eksudat akar kunyit.

2. Telur NSK yang berada di dalam sista tidak mengalami penurunan, karena faktor genetik setiap nematoda dan lingkungan yang mempengaruhi pembentukan telur nematoda.

3. Penggunaan jumlah kentang yang semakin banyak dalam sistem tumpangsari memperlihatkan bahwa jumlah sista akan semakin banyak, hal ini terlihat pada perlakuan 2 kentang dengan 1 kunyit $(317,11$ sista) yang dibandingkan dengan perlakuan 1 kentang dengan 1 kunyit (239,00 sista).

\section{DAFTAR PUSTAKA}

Achrom M, Kresnamurti TK, Dwi NH. 2011.Analisis dampak ekonomi nematoda sista kentang (Globodera rostochiensis (Woll) Behrens dan Globodera pallida (Stone) Behrens). Balai uji terap teknik dan metode karantina pertanian. Badan Karantina Pertanian, Kementerian Pertanian.

Altieri MA, Letourneau DK, Davis JR. 1983. Developing sustainable agroecosystems. J Bioscience 33(1):45-49.

Amirullah J dan Hadiyanti D. 2014. Keragaan produksi jarak tanam dan penerapan teknologi varietas kentang (Solanum tuberosum L) pada lahan dataran tinggi Propinsi Sumatera Selatan.

Bacic J, Stare BG, Sirca S et al. 2013. Morphometric and molecular analysis of potato cyst nematodes from Serbia. J Plant Protect Soc of Slovenia 5(6):369372.

Chitwood DJ. 2002. Phytochemical based strategies for nematode control. J Annu. Rev. phytopathol 40:221-248.

DOI: 10.1146/annurev.phyto.40.032602.130045.

Coyne DL, Talwana HAL, Maslen NR. 2003. Plant parasitic nematodes associated with root and tuber crops in Uganda. J Afri Plant Protect 9(2):87-98. 
Cronin D, Loccoz YM, Dunne C et al. 1997. Inhibition of egg hatch of the potato cyst nematode Globodera rostochiensis by chitinase producing bacteria. European J of Plant Pathol 103(433-440).

Damalas CA. 2011. Potential uses of turmeric (Curcuma longa) products as alternative means of pest management in crop production. J Plant Omics $4(3): 136-141$.

Dandurand LM, Morra M, Zasada I. 2016. Pale cyst nematode eradication research. Potato Progress Research \& Extension for Potato Industry of Idaho, Oregon \&Washington.

Direktorat Jenderal Hortikultura. 2003. Nematoda sista kuning (NSK), Globodera rostochiensis pada tanaman kentang.

Direktorat Jenderal Hortikultura. 2017. Laporan Kinerja Direktorat Jenderal Hortikultura, Kementerian Pertanian.

Gonzalez JA, Phillips MS. 1996. Behavior of potato cyst nematodes from the Canary Islands. J Nematol 28(4):451-456.

Indrawan D, Pasetyarini, Widyastuti SN. 2017. Pengaruh konsentrasi etanol dan lama waktu perendaman terhadap kemampuan deteksi nematoda sista kuning (Globodera spp). J Agroscience 7(1):220226.

Kusbiantoro D, Purwaningrum Y. 2018. Pemanfaatan kandungan metabolit sekunder pada tanaman kunyit dalam mendukung peningkatan pendapatan masyarakat. J Kultivasi 17(1): 544-549.

Mimee B, Dauphinais N, Belair G. 2015. Life cycle of the golden cyst nematode, Globodera rostochiensis, in Quebec, Canada. J Nematol 47(4): 290-295.

Seenivasan N. 2017. Status of potato cyst nematodes Globodera spp infection on potato at Kodaikanal hill of Tamil Nadu, India and yield loss estimation. J Ent and Zoo Studies 5(5):268-272.

Sharaby A, Rahman HA, Moawad SS. 2015. Intercropping system for protection the potato plant from insect infestation. J Eco Balkanica 7(1):87-92.

Sholehah DN, Amrullah A, Badami K. 2016. Identifikasi kadar dan pengaruh sifat kimia tanah terhadap metabolit sekunder kunyit (Curcuma domestica Val.) di Bangkalan. J Ilmiah Rekayasa 9(1):60-66.

USDA. 2012. Golden nematode program manual. United States Department of Agriculture, Marketing and Regulatory Programs, Animal and Plant Health Inspection Service, Plant Protection and Quarantine. p192.

Usman LA, Hamid AA, George OC et al. 2009. Chemical composition of rhizome essential oil of Curcuma longa L. growing in North Central Nigeria. J Chemi $4(2): 178-181$. 